\title{
Once more: When did globalisation begin?
}

\author{
KEVIN H. O'ROURKE†* AND JEFFREY \\ G. WILLIAMSON \\ $\dagger$ Department of Economics and IIIS, Trinity College, Dublin 2, Ireland \\ $\ddagger$ Department of Economics, Harvard University, Cambridge MA 02138, USA
}

Is globalisation 50, 500 or 5,000 years old? Most economists take the 'big bang' view, and think globalisation happened very recently. Most historians also take the big bang view, but point to globalisation in the distant past, citing famous dates like I492. We argued recently in this (O'Rourke and Williamson 2002a) and another journal (O'Rourke and Williamson 2002b) that both views are wrong. Instead, we argued that globalisation has evolved since Columbus, but that the most dramatic change by far took place in the nineteenth century. Economically significant globalisation did not start with I 405 and the first junk armadas heading west from China, or with I492 and Columbus sailing those little caravels west from Europe, or with I57I and the arrival in Manila of those stately galleons from Mexico. Globalisation became economically meaningful only with the dawn of the nineteenth century, and it came on in a rush.

It seems to us that no scholar should engage in this important debate about the historical origins of globalisation without first defining terms. Oddly enough, nobody else seems to do so. In contrast, we defined globalisation the way all economists are trained, as the integration of markets across space; and in the articles under discussion we concentrated on one dimension of globalisation, namely commodity market integration. The best way to gauge that historical process of market integration is to measure the extent to which prices of the same commodities converge over time worldwide. Where there is evidence of price convergence of spices between Malacca and Amsterdam, or of fine cotton goods between Calcutta and London, or of silver taels between China and Mexico, or of opium chests between Calcutta and Shanghai, then world market integration is at work. By identifying where and when such market integration has taken place over the centuries, we are in a far better position to debate what caused it - falling transport costs, lost trading monopolies, a return to peacetime conditions, or a switch from

\footnotetext{
* O'Rourke is a IRCHSS Government of Ireland Senior Fellow, and acknowledges generous support from the Irish Research Council for the Humanities and Social Sciences.
} 
anti-global to pro-global policy. The worst way to gauge that process is to measure only the changing amount of trade taking place between the markets, since those changes could be driven by supply and demand conditions within each trading region, the latter having nothing whatsoever to do with changing transport costs, trade monopolies, war embargoes, tariffs or quotas - that is, having nothing whatsoever to do with world market integration. Economic historians should care about the distinction, since it is far more useful to understand what explains the rise of world trade, than simply to measure it. And price behaviour is crucial to that explanation. It informs us as to whether it was world market integration or domestic demand and supply that caused some trade boom in commodities (including specie, by the way). The price behaviour at home of importable and exportable goods, relative to non-tradable goods, will help tell us which of five sources are doing most of the historical work - world market integration, demand boom at home, supply boom at home, demand boom abroad or supply boom abroad.

We are delighted that Dennis Flynn and Arturo Giráldez, such accomplished scholars of the pre-industrial world economy, have taken notice of our recent work on the origins of globalisation (Flynn and Giráldez 2004). Not surprisingly, they devote most of their essay to themes they know best the flow of specie - events that we never deny, but which they think we too casually ignore. They are also unhappy with our insistence that the historical debate should lean heavily on econometrics. Apart from this rhetoric, the Flynn-Giráldez critique is based on five assertions: that we have defined globalisation too narrowly; that we have ignored specie, a central part of trading arrangements; that we fail to appreciate 'path dependence'; that we err by characterising pre-industrial trade as dominated by luxuries; and that we have misread the role of local forces in China driving so much of world trade after Columbus. Our response will consider all five, but only after we have restated our definition of globalisation.

\section{Defining globalisation ${ }^{\mathrm{I}}$}

Our aim has been to explain the inter-continental trade boom that occurred in the wake of Columbus and Da Gama: that I.06 per cent per annum trade growth rate $1500-1799$ documented in Table $\mathrm{I}$, a rate that was perhaps three times the growth rate in European GDP, thus implying a rise in the trade share. We stress the word 'inter-continental' since our focus is on European trade with Asia and the Americas, not on trade within any of those three regions. ${ }^{2}$ The question we posed is this: Was this 'world' trade boom due to

I This section draws heavily on O'Rourke and Williamson (2002b), pp. 428-3I.

2 Thus, the evidence that 'world' market integration was far advanced within Europe during our period is not relevant to the present debate, although it is an important fact in its own 


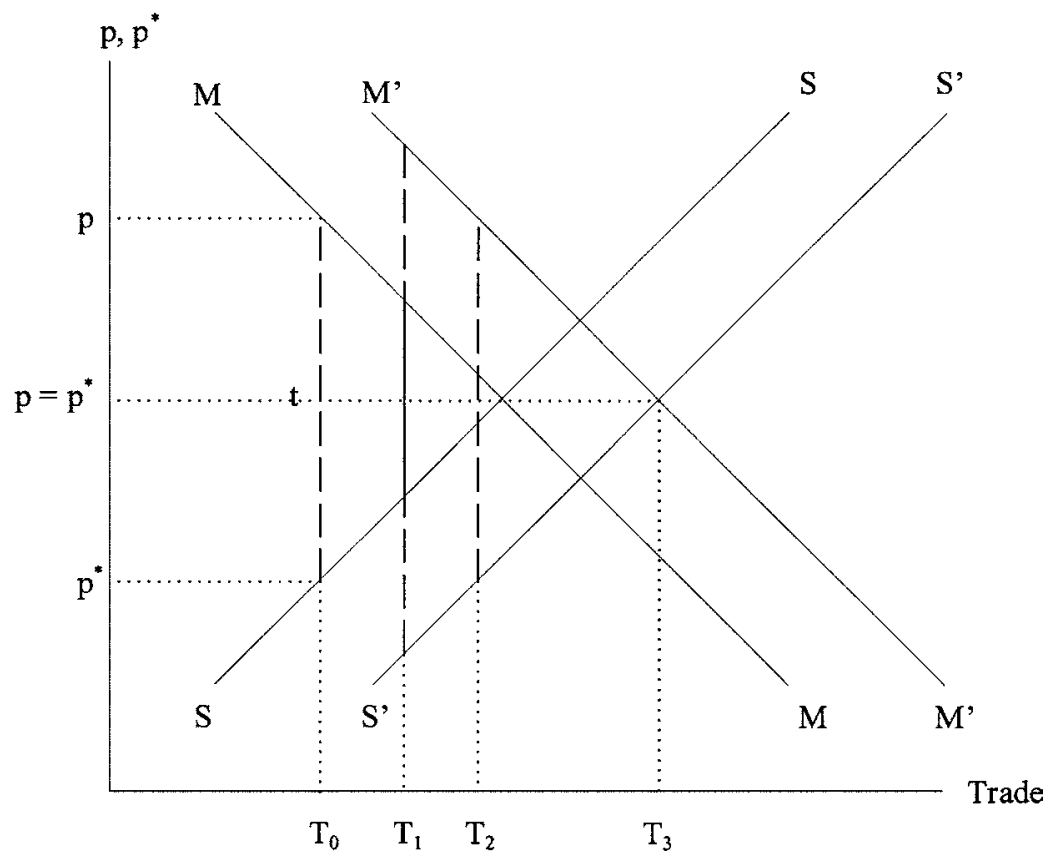

Figure I. Explaining the world trade boom.

market integration, or to demand and supply shifts in the various continents? For example, the expansion of European imports must have had its source in one (or in some combination) of three factors: a boom in the European demand for tradables, a boom in tradable supply from abroad, and a decline in barriers to trade between them. If a decline in trade barriers had accounted for the European overseas trade boom over the three centuries following I492, then market integration would have been the driving force. We are not searching for evidence of perfect market integration, of course, but rather for evidence of greater market integration, the latter in the form of commodity price convergence through time. Since we have not been able to find any significant evidence of commodity price convergence, but plenty of evidence confirming its absence, it follows that Euro-Asian and Euro-American trade must have boomed after I492 in spite of barriers to trade and anti-global mercantilist sentiment. There would have been a bigger trade boom without them. We stress that Flynn and Giráldez have not challenged this evidence or this inference from it.

Figure I presents a stylised view of trade between Europe and the rest of the world (the latter denoted by an asterisk). MM is Europe's import demand 
Table I. European and world intercontinental trade growth 1500-1992.

\begin{tabular}{ll}
\hline \hline Epoch & Per annum \% growth \\
\hline I500-I599 & I.26 \\
I600-I699 & 0.66 \\
I700-I799 & I.26 \\
I500-I799 & I.06 \\
I800-I899 & 3.85 \\
I900-I992 & 3.65 \\
I800-I992 & 3.70 \\
\hline \hline
\end{tabular}

Source: Revision and simplification of O'Rourke and Williamson (2002b, Table I, pp. 4I9-2I).

function (that is, domestic demand minus domestic supply), with import demand declining as the home market price $(p)$ increases. SS is the foreign export supply function (foreign supply minus foreign demand), with export supply rising as the price abroad $\left(p^{*}\right)$ increases. It is worth emphasising that SS is foreign supply less foreign demand; thus calling SS a 'foreign export supply function' does not exclude the possibility that demand conditions in Asia or the Americas help account for the inter-continental trade boom. ${ }^{3}$ Indeed, our work explicitly takes account of these foreign demand conditions.

In the absence of transport costs, monopolies, wars, pirates, and other trade barriers, world commodity markets would be perfectly integrated: prices would be the same at home and abroad, determined by the intersection of the two schedules. In practice, however, the various barriers always drive a wedge $(t)$ between export and import prices. World commodity market integration produces a decline in the wedge: falling transport costs, falling trading monopoly rents, falling tariffs, the suppression of piracy, or a return to peace all lead to falling import prices in both places, rising export prices in both places, an erosion of price gaps between them, and an increase in trade volumes connecting them.

The fact that trade should rise as trade barriers fall is, of course, the rationale behind using trade volumes (Table $\mathrm{I}$ ) or the share of trade in GDP as a proxy for international commodity market integration. Indeed, several authors have used Angus Maddison's data to trace out long-run trends in commodity market integration since the early nineteenth century, and historians of pre-industrial experience have used similar evidence (Hirst and Thompson 1996, Estevadeordal et al. 2003). However, Figure I makes it clear that world commodity market integration is not the only reason why the volume of trade, or trade's share in GDP, might increase over time. Just

\footnotetext{
${ }^{3}$ Note that we are talking about net export supply and net import demand, not simply supply and demand. Flynn and Giráldez have misinterpreted us here, as we shall see below.
} 
because we see a trade boom doesn't necessarily mean that more liberal trade policies, a breaking up of trade monopolies, or transport revolutions are at work. After all, outward shifts in either import demand (to $\mathrm{MM}^{\prime}$ ) or export supply (to SS') could also lead to trade expansion, and such shifts could occur as a result of population growth, the settlement of previouslyunexploited frontiers, capital accumulation, technological change, a shift in income distribution favouring those who import 'exotic' luxuries, and a variety of other factors. Alternatively, world commodity market integration could coincide with falling trade volumes if MM or SS were shifting inwards over time. Thus, Figure I argues that the only irrefutable evidence that world commodity market integration took place is a decline in the international dispersion of commodity prices, or what we call commodity price convergence. The central finding of our work is that there is very little evidence of world commodity price convergence in the three centuries after Columbus. And, to repeat, nowhere do Flynn and Giráldez challenge our evidence or our inference.

Figure I represents the post-I 492 trade boom documented in Table I as a rise from $\mathrm{T}_{\mathrm{O}}$ to $\mathrm{T}_{\mathrm{I}}, \mathrm{T}_{2}$ or $\mathrm{T}_{3}$. If $t$ remained constant (no net decline in trade barriers and no move toward more world commodity market integration), then outward shifts in either MM or SS, but not both, would generate a trade boom to $\mathrm{T}_{\mathrm{I}}$ (where the price gap, $t$, remains the same, although prices change in both markets). An outward shift in both MM and SS would generate a bigger trade boom to $\mathrm{T}_{2}$ (still holding $t$ constant). If at the same time $t$ evaporated (complete global commodity market integration), we would observe an even bigger trade boom to $T_{3}$. While we have used a simple empirical model to implement Figure I quantitatively, the far more important point is that the Figure offers an agenda. A really useful debate about globalisation during the three centuries after Columbus would collect the price data that would allow for explicit documentation of the forces at work. Was there commodity price convergence between trading partners (for example, did $t$ fall)? If so, which trading partners and when? And what were the main forces lowering $t$ ? A relaxation in some trading monopoly's grip? Falling transport costs? More pro-global policies? A move from war to peace? Moreover, evidence about the evolution of relative prices within local markets (not just between them) also offers a means by which qualitative assertions about the central forces at work can be accepted or rejected. Thus, did the relative price of tradables rise or fall in home markets? If so, which of the five forces accounts for it?

\section{Disease transfer, technology transfer and globalisation}

It seems to us that our agenda is broad enough to keep us busy for some time, but Flynn and Giráldez want it even broader. They favour expanding the 
globalisation assessment to include the transfer of flora, fauna and disease. Thus, a good share of their essay is devoted to listing the well-known and sometimes spectacular effects of disease and technology transfer. But it didn't take much European trade contact to spread syphilis and smallpox among the American population. Similarly, it only took one ship to bring the tomato to Europe, the potato to China, or the horse to North America. We agree and said so in the two articles they criticise - that these technology and disease transfers had a profound impact on all parts of the world connected by trade. But until it can be shown that the magnitude of these transfers rises systematically with the magnitude of trade - and such a quantitative exercise would be fascinating - such transfers and their impact can hardly be assigned to commodity market integration. To offer just one counter-example, the impact of the plague on fourteenth century Europe was bigger than the impact of HIV-AIDS on twenty-first century Africa, yet the former was hardly very integrated into the world economy. To repeat, we are interested in commodity market integration, and there is no reason why different dimensions of globalisation should not progress at very different rates.

\section{The impact of globalisation and path dependence}

Flynn and Giráldez define path dependence as cases where 'seemingly unimportant events can sometimes cause transformations of epic proportions' (p. 82). The critical part of this quote is the word 'seemingly', since unimportant events are just that, unimportant. In contrast, every economic historian believes that important events can persist long after the initial event is forgotten, and we believed that long before Paul David gave us the pathdependent label.

The impact of globalisation on the world economy will never be properly assessed until we agree on exactly how that impact is to be measured. Flynn and Giráldez do not offer any such measure, nor do they ever offer any measurement. We do. Traditional Heckscher-Ohlin trade theory makes it clear that big global economic events have their impact on economies first on relative commodity prices - as we have already discussed - and second on relative incomes and factor prices. In the pre-industrial world, the factors that mattered most were labour and land, and thus the factor prices that mattered most were wages and land rents. Any of the five forces underlying the trade boom described in Figure I will have a 'big' impact on the local economy only if local relative commodity prices are affected. When local prices are affected, labour will shift between sectors in response, consumption will shift towards the cheaper products, and the factors in heavier demand will improve their lot. When prices rise for the exportable, land-abundant countries increase their export commitment to the land-intensive good (such as wool or wine), while labour-abundant countries increase their export commitment 
to the labour-intensive good (such as cloth or porcelain). Wages rise relative to rents in labour-abundant countries, and rents rise relative to wages in land-abundant countries. Wage-rental ratios tend to converge between them.

When 'impact' is defined in this way, is there any evidence that globalisation had a big impact before I800? Everyone agrees that England evolved from being one of the central leaders of the European economy to being the central leader between I 500 and I 800 . So, what's the evidence on this 'impact' issue for the leader? Elsewhere we have shown that the terms of trade between agriculture and industry $\left(\mathrm{P}_{\mathrm{a}} / \mathrm{P}_{\mathrm{m}}\right)$ in England before $\mathrm{I} 800$ was driven primarily by the local endowment of land and labour: as the ratio of labour to land increased, $\mathrm{P}_{\mathrm{a}} / \mathrm{P}_{\mathrm{m}}$ rose, just as would be the case in a textbook closed economy (O'Rourke and Williamson 2002c). After I800, this 'closed' economy behaviour broke down, and $\mathrm{P}_{\mathrm{a}} / \mathrm{P}_{\mathrm{m}}$ was driven increasingly by world events and less and less by local endowments, signalling the appearance of an 'open' economy. Similarly, we showed that the wage-rent ratio (w/r) was driven almost entirely by local endowments before 1800: as the ratio of labour to land rose, $\mathrm{w} / \mathrm{r}$ fell. This 'closed' economy relationship broke down in the nineteenth century, when the English economy became more 'open' and when $w / r$ was influenced in part by $\mathrm{P}_{\mathrm{a}} / \mathrm{P}_{\mathrm{m}}$.

Flynn and Giráldez may wish to define 'impact' in some other way, but they haven't defined it at all - at least in any operational way. We have defined impact to our own liking, and by so doing have reached the conclusion that the world environment was poorly-linked and anti-global before I80o. It became better linked and more pro-global only afterwards. We invite our critics to define 'impact' in some different way, but insist that the definition be operational so that empirical assessments are possible.

\section{Luxuries versus necessities and intermediates}

Flynn and Giráldez argue that 'pre-I8th century global trade was not restricted to luxury items' and that it is 'misleading to label cowries, copper, low-quality silks, sugar, rhubarb, and many other Asian exports as luxury items throughout the period' (p. 9I). We do not disagree, but insist that the vast majority of intercontinental trade dealt with high-value, low-bulk goods like quality silks, precious metals, ceramics, and spices. This trade was never dominated by foodstuffs and low-quality textiles, the key consumption items for the working class and thus the majority of Europeans. Only in the nineteenth century did inter-continental trade become dominated by foodstuffs, cheap textiles and the intermediate primary products critical to European manufacturing (such as raw cotton, rubber, tin, copper and so on). The central point here is that the nature of commodities entering longdistance trade in the three centuries before 1800 was completely different than in the two centuries afterwards. 
In any case, the more important attribute of the commodities traded between continents in the three centuries after Columbus was as follows: rarely were these commodities what trade economists call competing goods. Rather, they were non-competing in the sense that imports of rhubarb, silk, tea and coffee did not directly displace domestic producers since those commodities were not produced in Europe. This non-competing attribute was crucial, since it minimised the impact of long-distance trade on resource allocation and factor prices locally: only when trade displaces local production do you get the reshuffling of productive factors which leads to economy-wide distributional changes.

\section{Specie and treasure}

Our work does not deal with specie flows and treasure. Flynn and Giráldez imply that by doing so we favour the hypothesis that silver flows were a passive balancing item in long-distance trade relationships. In contrast, they 'question the assertion that monetary metals flowed from Europe to Asia as a passive item used for balancing trade between the continents' (p. 84). While we do not have a position on this issue, it seems to us that this is an excellent illustration of how our methodological point on the usefulness of relative price information could be used to discriminate between the two competing hypotheses: silver flows were a passive balancing item in EuroAsian trade versus they were an active balancing item. If silver was passive, then when there were large trade flows driven by European demand, both the silver price of Chinese exportables and the balancing flow of silver would have been high. If instead silver was active, and thus if Chinese demands for silver mattered most, then the silver price of Chinese exportables would have been low when the silver flows were high. Which was it? We invite Flynn and Giráldez to supply the answer.

\section{Did the Chinese dog wag the European tail?}

Flynn and Giráldez are in error when they state:

In their fournal of Economic History article, an explicit ... model restricts 'import demand' to the European side of the equation, while 'export supply' rests exclusively on the Asian side of the ledger. As stated above, however, demand-side forces emanating from within China were a sine qua non in terms of the birth of global trade (p. 90).

On the contrary, we talked explicitly about Asian export supply, a net concept, equal to Asian supply minus Asian demand. To set the record straight, here's what we said:

Asian export supply of such goods as spices equaled Asian supply minus Asian demand. There is a traditional view which suggests that Asian demand may have declined from the fifteenth century onward, as China went increasingly autarkic. This would have had a major impact on the demand for internationally traded commodities, since China 
represented as much as a quarter of global GDP at that time. If true, this move would have represented a profound switch from what appears to have been a fairly open trade policy (O'Rourke and Williamson 2002b, pp. 439-40).

And then:

[This] speculation about a Chinese policy dog wagging a European tail is, of course, consistent with [the evidence] that European demand played no role in accounting for the trade boom in the sixteenth century, and that (non-Chinese) Asian supply accounted for all of it... These facts are also consistent with the view that China crowded in European trade with the rest of Asia over the three centuries following Da Gama. Of course, none of these facts can prove the hypothesis at hand; for that we would need Asian relative price evidence, which we currently lack (O'Rourke and Williamson $2002 \mathrm{~b}$, p. 442).

We would be delighted if Dennis Flynn, Arturo Giráldez, and other preindustrial world economy specialists were to take this empirical challenge seriously, and produce more long-run price data that can speak to the issues of when globalisation started, and what drove the post-Columbus expansion of world trade.

\section{References}

Estevadeordal, A., Frantz, B. and TAYlor, A. M. (2003). The rise and fall of world trade, 1870-1939. Quarterly fournal of Economics 108, pp. 359-407.

FLYNN, D. O. and GIRÁLDEZ, A. (2004). Path dependence, time lags and the birth of globalisation: a critique of O'Rourke and Williamson. European Review of Economic History 8, pp. 8I-I08.

HIRsT, P. Q. and THOMPSON, G. (1996). Globalisation in Question: The International Economy and the Possibilities of Governance. Cambridge: Polity Press. JACKS, D. (2000). Market integration in the North and Baltic Seas, I500-I800. LSE Working Paper in History 55/00 (London: London School of Economics).

O'Rourke, K. H. and Williamson, J. G. (2002a). When did globalisation begin? European Review of Economic History 6, pp. 23-50.

O'Rourke, K. H. and Williamson, J. G. (2002b). After Columbus: explaining Europe's overseas trade boom, I500-1800. Fournal of Economic History 62, pp. 417-56.

O'Rourke, K. H. and Williamson, J. G. (2002c). From Malthus to Ohlin: trade, growth and distribution since I500. NBER Working Paper 8955, National Bureau of Economic Research, Cambridge, MA. 